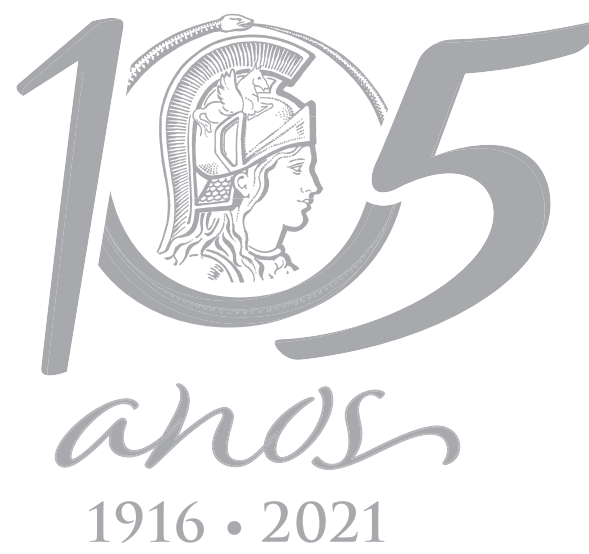

\title{
ECOSYSTEMS
}

\section{Ontogenetic diet shifts: an additional mechanism for successful invasion of a piranha species in a Neotropical floodplain}

\author{
GUSTAVO H. ZAIA ALVES, BRUNO R.S. FIGUEIREDO, GISLAINE I. MANETTA \& \\ EVANILDE BENEDITO
}

\begin{abstract}
Ontogenetic shifts in food preference reduces intraspecific competition as immature individuals eat different food types than adults. This diet plasticity could facilitate species' ability to successfully invade and establish itself in a new environment, even when co-occurring with phylogenetically close species. Here, ontogenetic diet shifts of a non-native piranha species (Serrasalmus marginatus) was tested by analyzing the relationship between its body length and the carbon and nitrogen stable isotope signatures. Carbon stable isotope was not correlated to fish length, but positive significant correlation between $\delta^{15} \mathrm{~N}$ values and fish length was found for the non-native piranha. Also, immature and adult S. marginatus showed low isotopic niche overlap. The correlation between fish length and $\delta^{15} \mathrm{~N}$, and the low trophic overlap between immature and adult, indicate that the non-native S. marginatus had ontogenetic shifts in food preference, which may be viewed as an additional mechanism underlying its successful establishment in the upper Paraná River. Our findings indicate that ontogenetic shifts in food preference may be an invasive trait that facilitates the establishment of non-native fish species in tropical aquatic systems.
\end{abstract}

Key words: coexistence, Serrasalmus, Paraná River, stable isotopes.

\section{INTRODUCTION}

Intrapopulational ontogenetic shifts in food preference is a process widely known for a variety of animal groups (insects - Cisneros \& Rosenheim 1997, crabs - Lim et al. 2016, and fishes - Sánchez-Hernández et al. 2012), which lead individuals to occupy different trophic positions throughout of their life cycle (Reum et al. 2019). If within a population, individuals exploit different resources, then the intraspecific resource overlap is reduced (Schröder et al. 2009, Reum et al. 2019), with positive implications for both fitness and the individual competitive abilities (Cipresso-Pereira et al. 2015). Ontogenetic diet shifts often occur as a result of the increases in body size, because slight increases in body size may result in bigger mouth size, which may enlarge the spectrum of exploitable food items (Bozza \& Hahn 2010). Many studies about fish diets have detected that juveniles are zooplanktivores, while adults are piscivores (Mittelbach \& Persson 1998, Davis et al. 2012). For example, Roeboides descalvadensis Fowler (1932) juveniles are zooplanktivores and as individuals grow, their teeth migrate outside of the mouth - a change in the animal's feeding appendages associated to ingestion of scales in adults (Hahn et al. 2000). In contrast, other fish species, such as the piranha Serrasalmus maculatus Kner, 1858, consume similar food items throughout their lives (e.g., fish in the case of S. maculatus), 
with high niche overlap between immature and adult individuals (Agostinho et al. 2003).

The ontogenetic shifts in addition to being essential to reduce the intraspecific competition may also be a key trait to species successfully colonizing new environments (Lavrinčíková \& Kováč 2007, Schröder et al. 2009). This is because the likelihood of a species successfully invading an ecosystem may vary not only according to the environment into which invaders were introduced but also according to the invaders' fitness (Elton 1958, Jeschke \& Strayer 2005). Therefore, if during somatic growth the individuals eat different types of food, then the probability of this species successfully invading a new environment would be higher than a species without such ontogenetic shifts in food preference (Lavrinčíková \& Kováč 2007, Hôrková \& Kováč 2015).

In the Parana River floodplain, the construction of the Itaipu hydroelectric power, in 1982, flooded a set of waterfalls (Sete Quedas falls), which formerly isolated the lower and upper portions of the river (Júlio Jr et al. 2009). The removal of these natural geographic barriers resulted in the invasion of 33 fish species, which were native to the lower basin, but migrated upstream and colonized the upper portion of the basin (Langeani et al. 2007, Casimiro et al. 2016). Amongst the non-native fish was the piranha Serrasalmus marginatus Valenciennes, 1837, which is overtaking its native congeneric, S. maculatus, in terms of population abundance, since 1986 (Agostinho 2003, Alves et al. 2017, Rodrigues et al. 2018). Although different spatial organization and trophic segregation between close-related piranha species seem to be amongst the mechanisms that underlie their coexistence (Alves et al. 2017, Rodrigues et al. 2018), it is still unclear what traits favored the establishment and spread of the non-native piranha species. One hypothesis is that the non-native S. marginatus have ontogenetic shifts in food preference while its native congeneric, $S$. maculatus do not (Agostinho et al. 2003). If so, then the ontogenetic shifts in food preference might represent an additional mechanism to explain the establishment success of $\mathbf{S}$. marginatus in the upper Paraná River.

Here, we evaluated the ontogenetic diet shifts of a non-native piranha species (S. marginatus) using an isotopic approach by analyzing the relationship between its standard length (SL) and stable isotope signatures (hereafter referred as $\delta^{13} \mathrm{C}$ and $\delta^{15} \mathrm{~N}$ ). Stable isotopes are useful tools to verify the ontogenetic diet shift because the assimilated food is revealed during their ontogenetic development (Manetta et al. 2011, Davis et al. 2012). Thus, considering that consumer's $\delta^{13} C$ and $\delta^{15} \mathrm{~N}$ signatures provide insights about diet shifts, especially during somatic growth (Davis et al. 2012), the prediction is that the non-native piranha species has an ontogenetic shift in its diet. In addition, we provided data regarding the relationship between SL and nitrogen stable isotopes for a smaller range of body-sizes of the native S. maculatus to indicate whether isotopic data follow the same trend found using stomach content analysis (Agostinho et al. 2003) - the lack of ontogenetic diet shift in native piranha.

\section{MATERIALS AND METHODS}

The isotopic composition $\left(\delta^{13} \mathrm{C}\right.$ and $\left.\delta^{15} \mathrm{~N}\right)$ of $S$. maculatus and S. marginatus was evaluated in three floodplain ponds associated with the Upper Paraná River, in South America (Figure 1). This floodplain is formed by a mosaic of aquatic habitats, including channels, tributaries, and floodplain ponds associated with these tributaries. All three floodplain ponds are shallow, have similar limnological conditions 


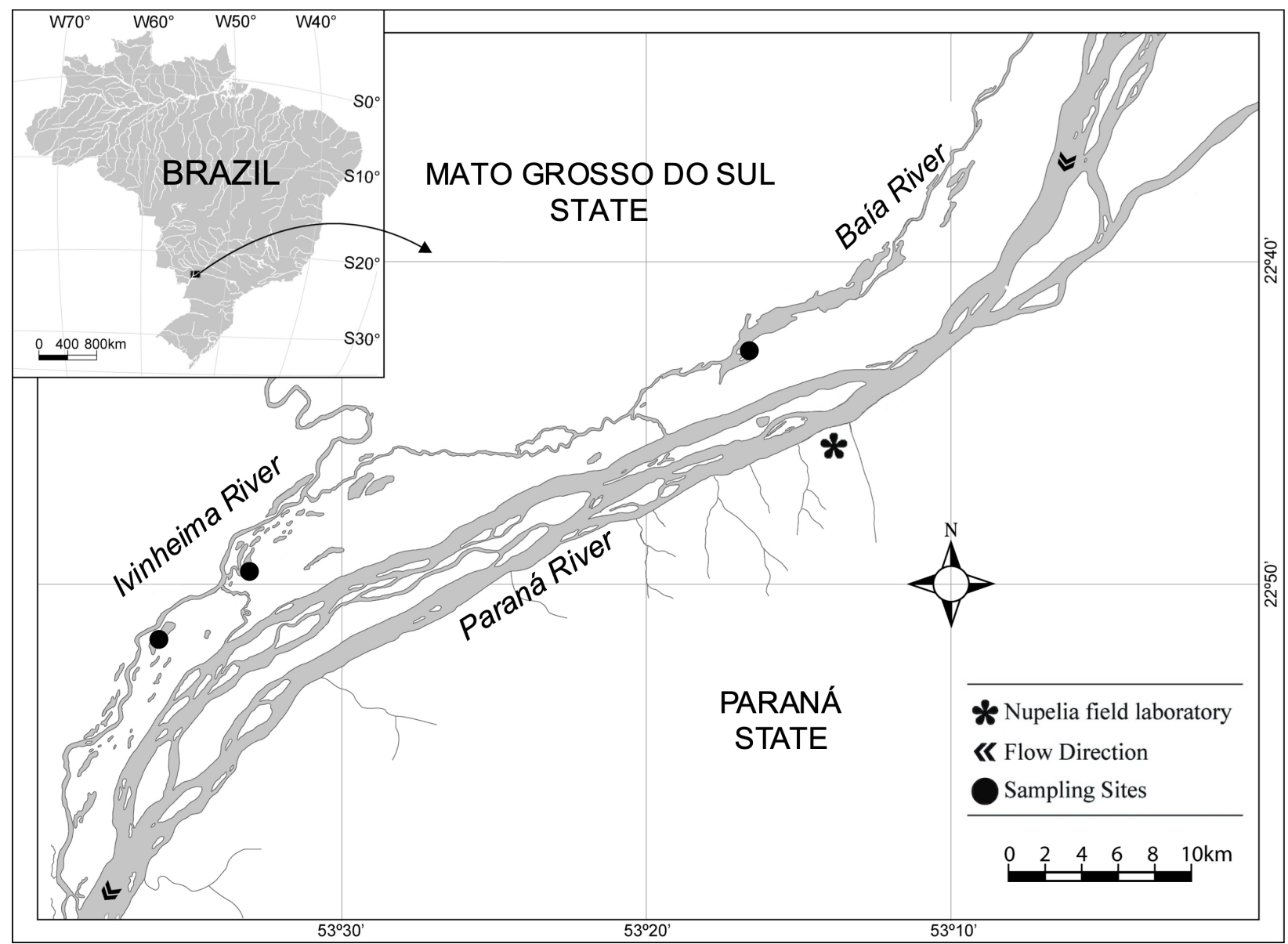

Figure 1. Study area. Points $(\cdot)$ indicate the ponds in which the fish samples were taken in the Upper Paraná River floodplain, located in southern Brazil.

(Roberto et al. 2009), with seasonal connections with the rivers or secondary channels during flood periods (Thomaz et al. 2004). Samples were taken during the dry season (September 2011) because, during this period, fish are confined within the ponds of the floodplain, minimizing the chances of migration to the main channel, and maximizing the probability of trophic interactions with their prey (Alves et al. 2017). The samples were obtained by using gill nets with different mesh sizes (ranging from 2.4 to $16.0 \mathrm{~cm}$ between opposite knots). The nets were exposed for a $24 \mathrm{~h}$ period and checked with an interval of 8 hours (at 8:00 AM, 4:00 PM, and 10:00 PM). The care and use of experimental animals complied with the Ethics Committee on the use of animals of the State University of Maringá animal welfare laws, guidelines and policies as approved by the permit number 123/2010-CEAE. The license to carry out sampling was registered in the Brazilian Institute of the Environment and Renewable Natural Resources (IBAMA) under the number 22442-3.

A total of 39 piranha individuals were sampled ( 14 native and 25 non-native species). Species from Serrasalmidae family present low abundance in relation to other fish species usually found in the fish assemblage of big rivers (Santos et al. 2017). All sampled fish were immediately packed in ice coolers and taken to the laboratory for biometric measurements and isotopic analysis preparation. In the laboratory, fish were anaesthetized using benzocaine and sacrificed with a cut in the spinal cord. 
Subsequently, fish were measured (standard length - SL) and weighed (standard weight - SW) and a muscle tissue sample was extracted from the base of the dorsal fin, for analysis of the ratio of carbon and nitrogen stable isotopes. The determination of isotope ratios was performed on an Isotope Ratio Mass Spectrometer from PDZ Europe ANCA-GSL with a PDC Europe 20-20 interface (Sercon Ltd., Cheshire, UK). The results were expressed in delta notation (parts per thousand deviation from a standard material): $\delta^{13} \mathrm{C}$ or $\delta^{15} \mathrm{~N}=\left[\left(R_{\text {sample }} / R_{\text {standard }}\right)-1\right]{ }^{*} 1000$; where $R={ }^{13} \mathrm{C} /{ }^{12} \mathrm{C}$ or ${ }^{15} \mathrm{~N} /{ }^{14} \mathrm{~N}$. The standard material for carbon was the international Vienna Pee Dee Belemnite (V-PDB) limestone, and the nitrogen standard was atmospheric nitrogen.

Ontogenetic shift in the diet of the nonnative piranha species was assessed testing the correlation (Pearson' method) between fish body length (standard length) and the raw values of carbon and nitrogen stable isotopes (used as a proxy of feeding habit). The limited size range data for native piranha hindered a direct comparison between the diets of both piranha species during their ontogenetic development. However, we presented the relationship between SL and nitrogen stable isotopes for a limited size range of the native piranha (Supplementary Material- Figure S1) as it could still be important to indicate whether isotopic data follow a similar trend found using stomach content analysis (Agostinho et al. 2003) - the lack of ontogenetic diet shift in native piranha. Raw values of $\delta^{15} \mathrm{~N}$ were used, instead of calculating the trophic position (TP), because of the uncertainty of primary sources for these fish species, which could bias the trophic position outcomes, and because of the lack of largebodied sessile primary consumer (e.g., snails or other molluscs) during sampling. All specimens inhabit the same floodplain ponds (i.e., they all co-occur in all three sampling habitats) that share similar limnological condition (Roberto et al. 2009) and a similar set of primary producers (e.g., Lopes et al. 2015, Benedito et al. 2018). Therefore, we assumed that the baseline was the same for all individuals, allowing comparisons of raw isotopic values. The Pearson correlation was carried out in the R software program $\mathrm{V}$. 3.6.0 (R Development Core Team 2019)

We assessed trophic differences between immature and adult S. marginatus, determined by the size (standard length) at first maturity (from 11.5 to $12.2 \mathrm{~cm}$ for male and female, respectively; Froese \& Pauly 2019). Then, we considered fish bigger than $12.2 \mathrm{~cm}$ as adult individuals. All sampled S. maculatus were adults (they were bigger than $10.8 \mathrm{~cm}$; Froese \& Pauly 2019). We calculated the standard ellipse area (SEA) for each size-class category (Jackson et al. 2011) to test whether immature and adult non-native individuals exploit similar feeding resources. The SEA is a representation of the isotopic niche and contains ca. $40 \%$ of the data; is expressed in $\%{ }^{2}$. We corrected the SEA for the small sample size to increase the reliability. This correction is useful because it allows comparisons between different (and/or small) sample sizes. We indicated such correction by the letter " $\mathrm{c}$ " after SEA: SEAc. Also, we estimated the areas of the ellipses associated with each size-class category using Bayesian modelling $\left(S_{E} A_{B}\right)$ to assess possible differences in the sizes of the isotopic niche (Jackson et al. 2011). SEA $A_{B}$ is calculated using an iterative model based on Bayesian inference to estimate the covariance matrix from the isotope data. SEA $A_{B}$ considers variability in the data (caused by natural variations and analytical error) more efficiently and provides a distribution of solutions rather than a single value, therefore allowing error estimates as well as pairwise comparisons (Jackson et al. 2011). Here, the number of iterations was set to $10^{4}$. Differences in the size of isotopic niches were 
evaluated by calculating the probability that the relative posterior distribution of immature isotopic niche size to be smaller or larger than that of the adult individuals (Jackson et al. 2011). We considered a probability of $>0.95$ to reflect noteworthy differences in the size of the niche breadth. Both SEAc and SEA ${ }_{B}$ analysis were conducted in the $\mathrm{R}$ package SIBER v. 2.1.4 (R Development Core Team 2019, Jackson et al. 2011).

Trophic niche overlap between adult and immature fish was estimated using the R package nicheROVER v. 1.0 (Lysy et al. 2014, Swanson et al. 2015), which provides estimates of overlap that are insensitive to small sample sizes. To account for uncertainty and sample size variations the package applies a Monte Carlo estimation on the niche overlap (10,000 steps) (Swanson et al. 2015). Then, the trophic niche overlap is calculated as the probability of each fish size-class category (immature and adult individuals) to be found in each other posterior ellipses (Swanson et al. 2015). Also, to assess possible differences for each isotope between immature and adults a one-way analysis of variance (ANOVA) was conducted using the SPSS ${ }^{\circledR}$ software program. The level of significance for all analysis was set at $p<0.05$.

\section{RESULTS}

The standard length varied from 16.0 to 23.0 $\mathrm{cm}$ for native and from 7.0 to $21.5 \mathrm{~cm}$ for nonnative piranha species (Table I). No correlation was found between the fish standard length and $\delta^{13} \mathrm{C}$ for S. marginatus $(\mathrm{R}=0.24, t=1.17, p=0.13)$. Therefore, the non-native piranha population do not shift the exploited primary energy source as they grow. In addition, the non-native piranha $\delta^{15} \mathrm{~N}$ was positively correlated with fish standard length $(R=0.53, t=2.97, p<0.01$; Figure 2$)$.

Non-native adult individuals were enriched in $\delta^{15} \mathrm{~N}\left(F_{1,23}=16.98, p<0.001\right)$, but had no different values of $\delta^{13} \mathrm{C}$ from those of immature individuals $\left(F_{1,23}=1.99, p=0.17\right)$. Regarding the isotopic niche width, we observed a smaller SEAc for adult S. marginatus (SEAC $=1.45 \%{ }^{2}$ ) compared to immature individuals $\left(\right.$ SEAC $\left.=1.89 \%{ }^{2}\right)$ (Figure 3; Table I). The model-estimated standard ellipse area $\left(S E A_{B}\right)$ of adult individuals was smaller than that of the immature individuals in more than $65 \%$ of model runs, evidencing a larger trophic niche trend associated with immature individuals (Table I). Analysis of trophic overlap based on Bayesian posterior ellipses distributions showed that both categories of S. marginatus had a low probability of assimilating the same resources (considering an ellipse with $40 \%$ of the data):

Table I. Mean ( \pm Standard Deviation) of standard length $(\mathrm{SL})$ and of $\delta^{13} \mathrm{C}$ and $\delta^{15} \mathrm{~N}$ values of each fish species. All Serrasalmus maculatus were adult individuals. Adult and immature represent the size-class categories of the non-native piranha Serrasalmus marginatus and its respective isotopes and size. For each species, and life stage (where possible) is the number of sampled individuals ( $n$ ), the standard length (SL), corrected standard ellipse area (SEAC) and the mode of model-estimated standard ellipse area $\left(\mathrm{SEA}_{\mathrm{B}}\right.$ - lower and upper $95 \%$ confidence interval).

\begin{tabular}{|c|c|c|c|c|c|c|}
\hline $\begin{array}{c}\text { Species / Life } \\
\text { stages }\end{array}$ & $\mathbf{n}$ & $\mathbf{S L}(\mathbf{c m})$ & $\mathbf{\delta}^{13} \mathbf{C}(\% \mathbf{\%})$ & $\mathbf{\delta}^{\mathbf{1 5}} \mathbf{N}(\% \mathbf{)}$ & $\mathbf{S E A C}\left(\% \mathbf{o}^{2}\right)$ & $\mathbf{S E A}_{\mathbf{B}}\left(\%^{2}\right)$ \\
\hline S. maculatus & 14 & $17.89( \pm 1.87)$ & $-27.89( \pm 1.11)$ & $11.09( \pm 0.44)$ & - & - \\
\hline S. marginatus & 25 & $13.34( \pm 3.62)$ & $-29.55( \pm 1.28)$ & $11.05( \pm 0.66)$ & - & - \\
\hline Adult & 14 & $15.93( \pm 2.42)$ & $-29.24( \pm 1.22)$ & $11.42( \pm 0.57)$ & 1.45 & $1.39(0.82-2.49)$ \\
\hline Immature & 11 & $10.05( \pm 1.58)$ & $-29.95( \pm 1.30)$ & $10.57( \pm 0.43)$ & 1.89 & $1.62(0.83-3.06)$ \\
\hline
\end{tabular}


adult has about $12 \%$ of probability to be found in the immature isotopic niche, while immature has approximately $7 \%$ of probability to be found in the adult isotopic niche (Figure 4).

\section{DISCUSSION}

The correlation between $\delta^{13} \mathrm{C}$ and $\delta^{15} \mathrm{~N}$ signatures and fish length was tested in a non-native piranha species, which invaded the Paraná River after the removal of a geographical barrier ca. 30 years ago (Júlio Jr. et al. 2009). Isotopic carbon signatures was not correlated to their standard length, but $\delta^{15} \mathrm{~N}$ were positively correlated with fish length. Also, adult and immature non-native piranha species showed low isotopic niche overlap. The findings of this study show that the non-native piranha species (S. maculatus) has ontogenetic shifts in food preference. The 'theory of alternative ontogeny and invasive potential' (Kováč 2010) considers that successful invaders may have narrower niche breadth in their native areas (i.e., where the selective pressure shapes the organism' traits) and they are more generalists in areas they have invaded. The existence of such biological plasticity contributes to non-native species successfully colonizing a new environment (Lavrinčíková \& Kováč 2007, Hôrková \& Kováč 2015). Thus, although we have no data regarding the $S$. marginatus diet in their native area, their ontogenetic diet shift in the area they have invaded can be viewed as an invasive trait that facilitated their establishment

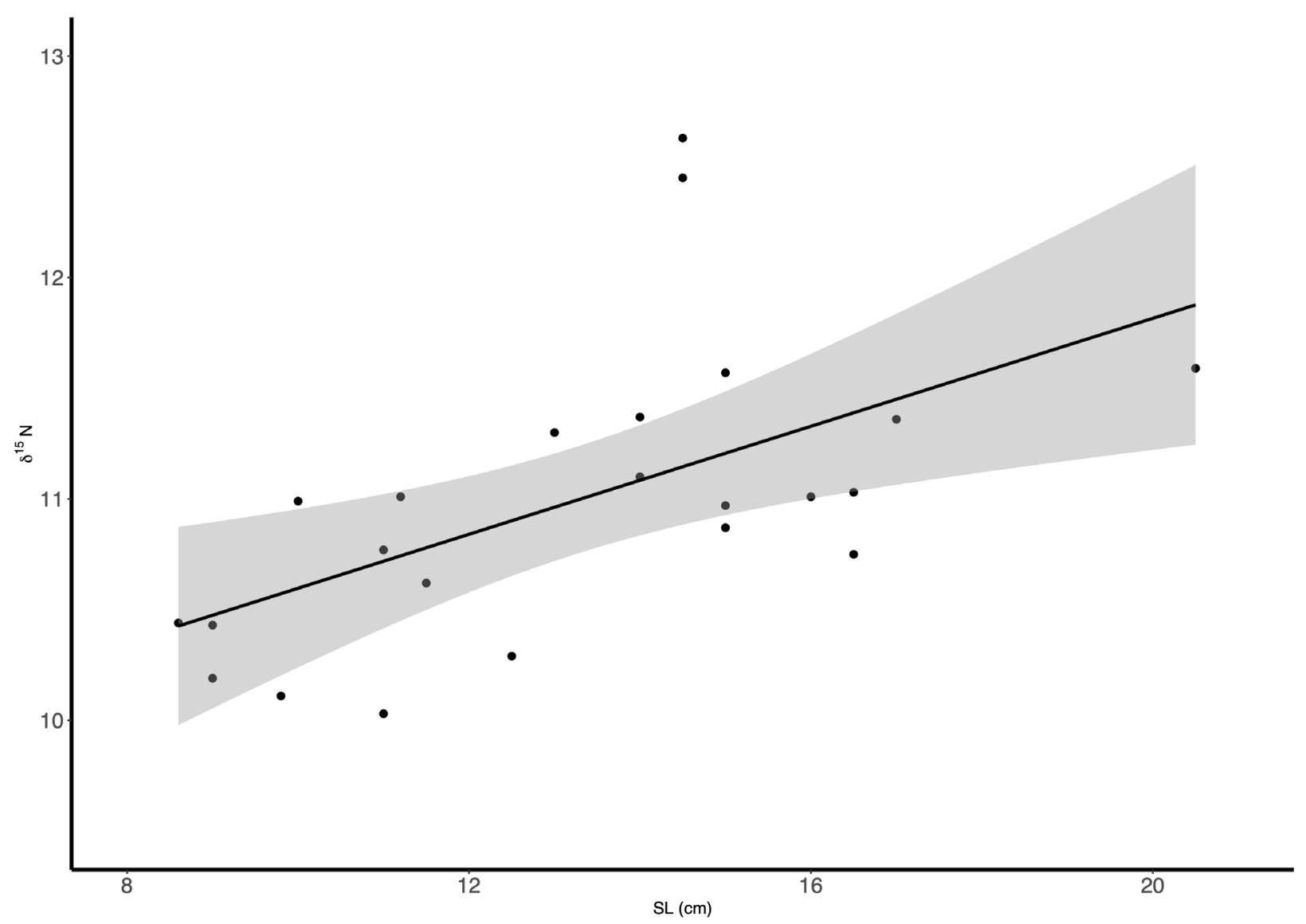

Figure 2. Relationship between standard length $(\mathrm{SL})$ and raw values of $\delta^{15} \mathrm{~N}$ in the non-native piranha Serrasalmus marginatus $(R=0.53 ; t=2.97 ; p<0.01)$. Grey shading around the regression line indicates the $95 \%$ confidence interval. 
(Grabowska \& Przybylski 2015, Nagelkerke et al. 2018). Therefore, we suggest that ontogenetic shift in food preference of $S$. marginatus is one mechanism that facilitates the successful establishment of this non-native piranha species. Such a mechanism is complementary to others that have been reported, such as the segregation of food resources (Alves et al. 2017) and the ability to occupy different habitats (e.g., reproducing in lotic environments) from its native congeneric in the Paraná River floodplain (Rodrigues et al. 2018).

Post (2002) suggests that for an increase in one trophic level, aquatic consumers should be enriched in their $\delta^{15} \mathrm{~N}$ in ca. $3.4 \%$ o. Here, although non-native individuals have different $\delta^{15} \mathrm{~N}$ values as they grow, the difference between smallest and biggest individuals was on average $1 \%$. Therefore, individuals of non-native piranha species did not change their trophic position as they grow. Recognizing that prey with larger body sizes have higher $\delta^{15} \mathrm{~N}$ values in their tissue (Fry 2006, Kawakami et al. 2019), then the positive relationship between $S L$ and $\delta^{15} \mathrm{~N}$ may be a result of the consumption of larger prey as the nonnative piranha grow. Six other piscivorous fishes in the same floodplain showed the pattern of consuming larger prey with the increase of their body size (Bozza \& Hahn 2010).

Additionally, one might expect that piranha would not consume large-bodied fish prey as they grow because these fish are known for taking bites instead of consuming the whole fish (e.g., Nico \& Taphorn 1988, Agostinho et al. 2003). Thus, biting larger piscivorous predators could be a risk since the piranhas can become easy prey of these large-bodied fish. On the other hand, taking more risk is an expected result in terms of getting high-quality food because the amount of protein and energy embodied in large fish are usually high (i.e., following the 'Optimal foraging theory'; MacArthur \& Pianka 1966, Emlen 1966). Therefore, in order to maximize its overall rate of energy gain, large prey should be the most profitable prey for piranhas to fulfil their growing energy needs, especially in invaded

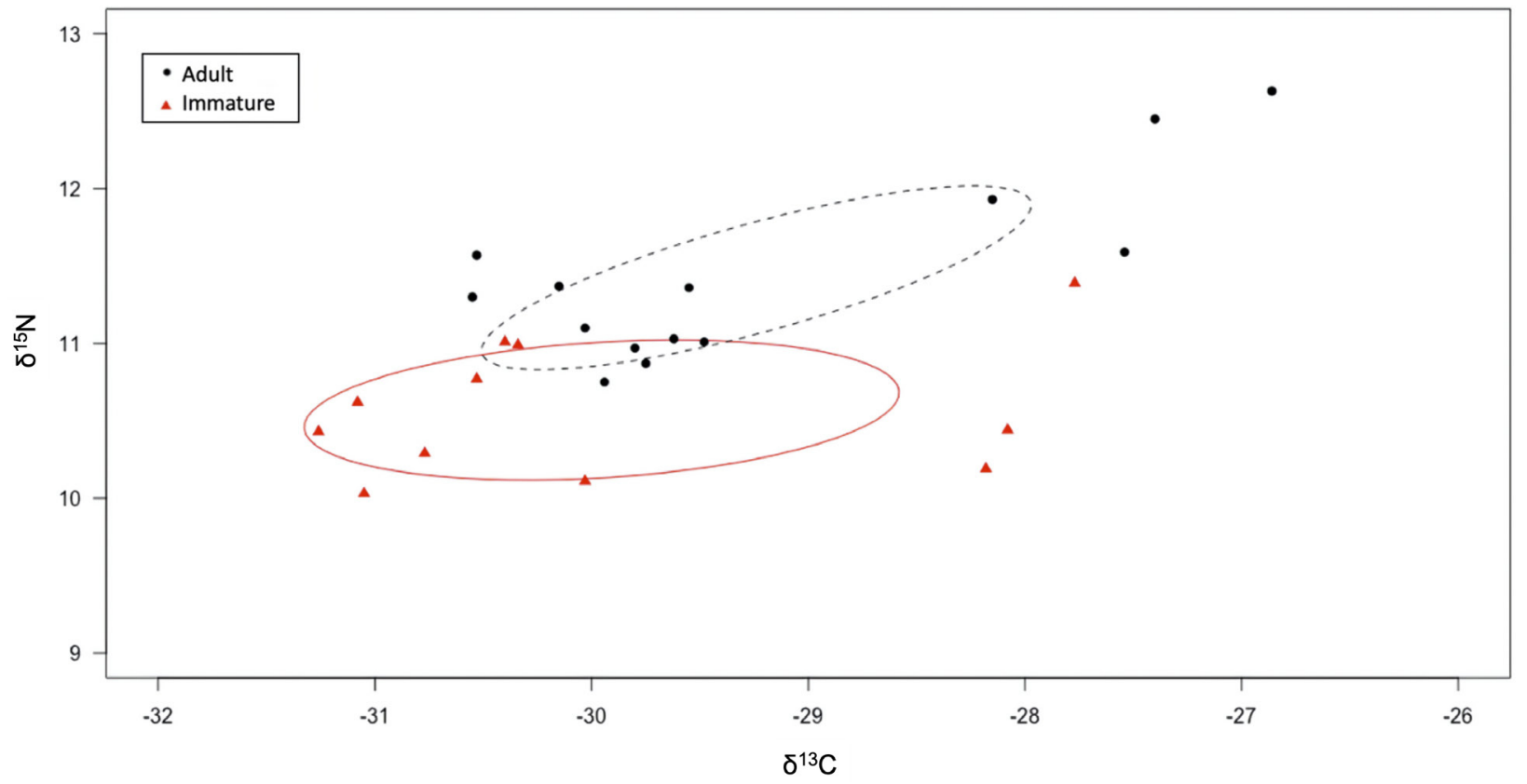

Figure 3. Stable isotopes values of carbon $\left(\delta^{13} \mathrm{C}\right)$ and nitrogen $\left(\delta^{15} \mathrm{~N}\right)$ and Standard Ellipses Areas (SEAC) for immature (red solid ellipse) and adult (black dashed ellipse) individuals of the non-native piranha Serrasalmus marginatus. 
habitats where there is native congeneric as a possible competitor (Agostinho et al. 2003, Alves et al. 2017).

Another hypothesis is that fish becomes increasingly important to the non-native piranha's diet as it grows, while piranhas with small/intermediate body size mix their diet with fish and other food types (like invertebrates). Trophic specialization is a wide known phenomenon for many fish species, especially for piscivores (e.g., Manetta et al. 2011, Davis et al. 2012). For example, Grey (2001) showed a marked ontogeny and specialization for the brown trout from Loch Ness, with bigger individuals having high values of $\delta^{15} \mathrm{~N}$ and narrow isotopic range. Bozza \& Hahn (2010) also found that four (out of six) adult piscivorous fish showed narrower niche breadth compared to immature individuals. Our results showed that adult fish had a smaller isotopic niche in most of the posterior distributions of the Bayesian model (i.e., ca. 65\%). Although not significant, this analysis showed a trend with a more specialized adult feeding habit and even slight shifts in food preference can reduce niche overlap facilitating the coexistence among individuals within a fish population.

Identifying whether the species ability to invade a new environment is associated with specific traits is important to predict which species can rapidly spread and cause local species extinctions where it is not native (Pyšek \& Richardson 2007, Vitule et al. 2009, Figueiredo et al. 2018, Nagelkerke et al. 2018). One way to identify such invasive traits is to look for trait differences between native and non-native

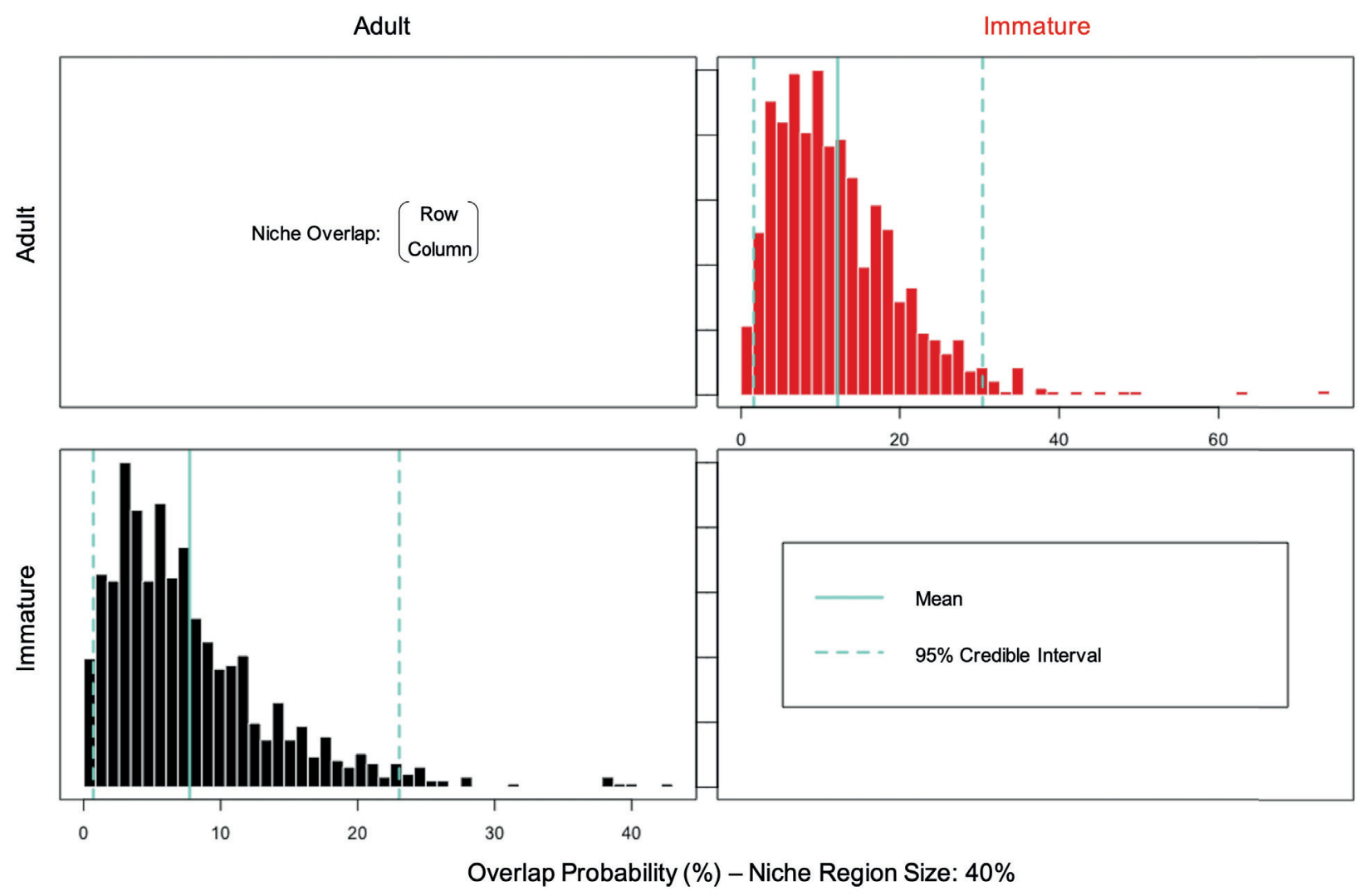

Figure 4. Posterior distribution of percentage overlap of $40 \%$ niche regions between Adult and Immature populations of Serrasalmus marginatus. Niche overlap is defined as the probability that an individual from one category (rows) is found within the niche region of the other category (columns). 
species, such differences could allow the nonnative species to occupy unfilled niches and then establish itself in a new environment (van Kleunen et al. 2010, Grabowska \& Przybylski 2015). In the case of piranhas, Agostinho et al. (2003) using stomach content analysis found that native piranha had a high intraspecific trophic overlap between juveniles and adults, while our findings showed low trophic overlap between juveniles and adults for non-native piranha. Therefore, we suggest that the differences in foraging behavior during ontogenetic development presented by the non-native piranha could be a key life history trait that could facilitate its establishment in the Upper Paraná River floodplain. Furthermore, previous evidence suggests that differences in other behavioral features such as aggressiveness could favor non-native over native piranha species (Agostinho et al. 2003), which would explain why the non-native piranha is overtaking its native congeneric. Our findings suggest that ontogenetic diet shifts may be an additional mechanism for non-native fish species successfully establish populations in tropical aquatic systems.

\section{Acknowledgments}

The authors thank Nupélia/UEM, the CNPq/SISBIOTA project, the Graduate Program in Ecology of Continental Aquatic Environments (Programa de Pós-Graduação em Ecologia de Ambientes Aquáticos Continentais - PEA); CNPq/PELD for financial support and infrastructure to develop the study, and CNPq (Conselho Nacional de Desenvolvimento Científico e Tecnológico) and CAPES (Coordenação de Aperfeiçoamento de Pessoal de Nivel Superior) for the scholarship granted to Gustavo H. Z. Alves, Bruno R. S. Figueiredo and Gislaine I. Manetta. The authors also thank three anonymous reviewers for valuable suggestions for improving the manuscript. This work was partially supported by CAPES, an organ of the Brazilian Government for the training of human resources.

\section{REFERENCES}

AGOSTINHO CS. 2003. Reproductive aspects of Piranhas Serrasalmus spilopleura and Serrasalmus marginatus into the Upper Paraná River, Brazil. Braz J Biol 63: 1-6.

AGOSTINHO CS, HAHN NS \& MARQUES EE. 2003. Patterns of food resource use by two congeneric species of piranhas (Serrasalmus) on the Upper Paraná River floodplain. Braz J Biol 63: 177-182.

ALVES GHZ, FIGUEIREDO BRS, MANETTA GI, SACRAMENTO PA, TÓFOLI RM \& BENEDITO E. 2017. Trophic segregation underlies the coexistence of two piranha species after the removal of a geographic barrier. Hydrobiologia 797: 57-68.

BENEDITO E, SANTANA ARA \& WERTH M. 2018. Divergence in energy sources for Prochilodus lineatus (Characiformes: Prochilodontidae) in Neotropical floodplains. Neotrop Ichthyol 16: e160130.

BOZZA A \& HAHN NS. 2010. Uso de recursos alimentares por peixes imaturos e adultos de espécies piscivoras em uma planície de inundação neotropical. Biota Neotrop 10: 217-226.

CASIMIRO ACR, GARCIA DAZ, COSTA ADA, BRITTON JR \& ORSI ML. 2016. Impoundments facilitate a biological invasion: Dispersal and establishment of nonnative armoured catfish Loricariichthys platymetopon (Isbrückler and Nijssen, 1979) in a Neotropical river. Limnologica 62: 34-37.

CIPRESSO-PEREIRA PH, PEREIRA P \& MUNDAY GPJ. 2015. Competitive mechanisms change with ontogeny in coraldwelling gobies. Ecology 96: 3090-3101.

CISNEROS J \& ROSENHEIM J. 1997. Ontogenetic change of prey preference in the generalist predator Zelus renardii and its influence on predator-predator interactions. Ecol Entomol 22: 399-407.

DAVIS AM, BLANCHETTE ML, PUSEY BJ, JARDINE TD \& PEARSON RG. 2012. Gut content and stable isotope analyses provide complementary understanding of ontogenetic dietary shifts and trophic relationships among fishes in a tropical river. Freshwater Biol 57: 2156-2172.

ELTON CS. 1958. The ecology of invasions by animals and plants. Methuen, London: Chapman and Hall Ltd.

EMLEN JM. 1966. The role of time and energy in food preference. Am Nat 100: 611-617.

FIGUEIREDO BRS, FIORI LF, KEPPELER FW, MORMUL RP \& BENEDITO E. 2018. Non-lethal effects of a native and a non-native piscivorous fish on the interaction between 
a mesopredator and benthic and pelagic invertebrates. Aquat Invasions 13: 553-563.

FROESE R \& PAULY D. 2019. FishBase. World Wide Web electronic publication. Available at www.fishbase.org (last accessed 10 June 2019).

FRY B. 2006. Stable Isotope Ecology. New York: Springer.

GRABOWSKA J \& PRZYBYLSKI M. 2015. Life-history traits of non-native freshwater fish invaders differentiate them from natives in the Central European bioregion. Rev Fish Biol Fisheries 25: 165-178.

GREY J. 2001. Ontogeny and dietary specialization in brown trout (Salmo trutta L.) from Loch Ness, Scotland, examined using stable isotopes of carbon and nitrogen. Ecol Freshw Fish 10: 168-176.

HAHN NS, PAVANELLI CS \& OKADA EK. 2000. Dental development and ontogenetic diet shifts of Roeboides paranensis Pignalberi (Osteichthyes, Characinae) in pools of the Upper Rio Paraná floodplain (state of Paraná, Brazil). Rev Bras Biol 60: 93-99.

HÔRKOVÁ K \& KOVÁČ V. 2015. Ontogenetic phenomena, temporal aspect, and ecological factors in the successful invasion of round goby Neogobius melanostomus in the River Danube. Aquat Invasions 10: 227-235.

JACKSON AL, INGER R, PARNELL AC \& BEARHOP S. 2011. Comparing isotopic niche widths among and within communities: SIBER - Stable Isotope Bayesian Ellipses in R. J Animal Ecol 80: 595-602.

JESCHKE JM \& STRAYER DL. 2005. Invasion success of vertebrates in Europe and North America. Proc Natl Acad Sci 102: 7198-7202.

JÚLIO JR HF, TÓS CD, AGOSTINHO AA \& PAVANELLI CS. 2009. A massive invasion of fish species after eliminating a natural barrier in the upper rio Paraná basin. Neotrop Ichthyol 7: 709-718.

KAWAKAMI T, SAITO T, NISHIDA K, YAMAKAWA T \& OTAKE T. 2019. Relationships between growth traits and scale stable isotopes $\left(\delta^{13} \mathrm{C}, \delta^{15} \mathrm{~N}\right)$ of adult chum salmon Oncorhynchus keta in Hokkaido, Japan. J Appl Ichthyol 35: 570-575.

KOVÁČ V. 2010. Developmental plasticity and successful fish invasions. In: PROCEEDINGS OF $17^{\text {TH }}$ INTERNATIONAL CONFERENCE ON AQUATIC INVASIVE SPECIES. Available at https://www.icais.org/pdf/abstracts_2010.pdf (last accessed 28 May 2019).

LANGEANI F, CASTRO RMC, OYAKAWA OT, SHIBATTA OA, PAVANELLI CS \& CASATTI L. 2007. Diversidade da ictiofauna do Alto Rio Paraná: composição atual e perspectivas futuras. Biota Neotrop 7: 181-197.
L'AVRINČÍKOVÁ M \& KOVÁČ V. 2007. Invasive round goby Neogobius melanostomus from the Danube mature at small size. J Appl Ichthyol 23: 276-278.

LIM SSL, YONG AYP \& CHRISTY JH. 2016. Ontogenetic changes in diet and related morphological adaptations in Ocypode gaudichaudii. Invertebrate Biology 135: 117-126.

LOPES CA, MANETTA GI, FIGUEIREDO BRS, MARTINELLI LA \& BENEDITO E. 2015. Carbon from littoral producers is the major source of energy for bottom-feeding fish in a tropical floodplain. Envrion Biol Fish 98: 1081-1088.

LYSY M, STASKO AD \& SWANSON HK. 2014. nicheROVER: (Niche) (R)egion and Niche (Over)lap Metrics for Multidimensional Ecological Niches. R package version 1.0. https://CRAN.R-project.org/package=nicheROVER.

MACARTHUR RH \& PIANKA ER. 1966. On optimal use of a patchy environment. Am Nat 100: 603-609.

MANETTA GI, BIALETZKI A, NETO CS, MARTINELLI LA \& BENEDITO E. 2011. Ontogenetic changes in the food items assimilated by Plagioscion squamosissimus (Perciformes: Sciaenidae) and Hypophthalmus edentatus (Siluriformes: Pimelodidae). J Freshwater Ecol 26: 315-321.

MITTELBACH GG \& PERSSON L. 1998. The ontogeny of piscivory and its ecological consequences. Can J Fish Aquat Sci 55: 1454-1465.

NAGELKERKE L, VAN ONSELEN E, VAN KESSEL N \& LEUVEN R. 2018. Functional feeding traits as predictors of invasive success of alien freshwater fish species using a foodfish model. PLoS ONE 13: e0197636.

NICO L \& TAPHORN D. 1988. Food habits of Piranhas in the Low Llanos of Venezuela. Biotropica 20: 311-321.

POST DM. 2002. Using stable isotopes to estimate trophic position: models, methods, and assumptions. Ecology 83: 703-718.

PYŠEK P \& RICHARDSON DM. 2007. Traits associated with invasiveness in alien plants: where do we stand? In: Nentwig W (Ed), Biological Invasions. Berlin, Germany: Springer-Verlag, 97-125.

R DEVELOPMENT CORE TEAM. 2019. R: A language and environment for statistical computing. Vienna, Austria: R Foundation for Statistical Computing. https://www.Rproject.org/.

REUM JC, BLANCHARD JL, HOLSMAN KK, AYDIN K \& PUNT AE. 2019. Species-specific ontogenetic diet shifts attenuate trophic cascades and lengthen food chains in exploited ecosystems. Oikos 128: 1051-1064.

ROBERTO MC, SANTANA NF \& THOMAZ SM. 2009. Limnology in the Upper Paraná River floodplain: large-scale spatial and temporal patterns, and the influence of reservoirs. Braz J Biol 69: 717-725. 
RODRIGUES AC, SANTANA HS, BAUMGARTNER MT \& GOMES LC. 2018. Coexistence between native and nonnative species: the invasion process and adjustments in distribution through time for congeneric piranhas in a Neotropical floodplain. Hydrobiologia 817: 279-291.

SÁNCHEZ-HERNÁNDEZ J, SERVIA MJ, VIEIRA-LANERO R \& COBO F. 2012 Ontogenetic dietary shifts in a predatory freshwater fish species: the brown trout as an example of a dynamic fish species. In: Tirker H (Ed) New advances and contributions to fish biology, InTech, London, UK, p. 271-298.

SANTOS AC, GONÇALVES CC \& CARVALHO FR. 2017. Ichthyofauna of the "Cachoeira de São Roberto" and fishes of lower Preto River, upper Paraná River basin, Brazil. Biota Neotropica 17: e20160196.

SCHRÖDER A, NILSSON KA, PERSSON L, VAN KOOTEN T \& REICHSTEIN B. 2009. Invasion success depends on invader body size in a size-structured mixed predationcompetition community. J Animal Ecol 78: 1152-1162.

SWANSON HK, LYSY M, POWER M, STASKO AD, JOHNSON JD \& REIST JD. 2015. A new probabilistic method for quantifying n-dimensional ecological niches and niche overlap. Ecology 96: 318-324.

THOMAZ SM, PAGIORO TA, BINI LM, ROBERTO MC \& ROCHA RRA. 2004. Limnological characterization of the aquatic environments and the influence of hydrometrics levels. In: Thomaz SM, Agostinho AA \& Hahn NS (Eds), The Upper Paraná River and Its Floodplain: Physical Aspects, Ecology and Conservation, Backhuys Publishers (p. 75102). Leiden, The Netherlands.

VAN KLEUNEN M, WEBER E \& FISCHER M. 2010. A meta-analysis of trait differences between invasive and non-invasive plant species. Ecol Lett 13: 235-245.

VITULE JRS, FREIRE CA \& SIMBERLOFF D. 2009. Introduction of non-native freshwater fish can certainly be bad. Fish Fish 10: 98-108.

\section{SUPPLEMENTARY MATERIAL}

Figure S1. Relationship between standard length $(\mathrm{SL})$
and nitrogen stable isotope $\left(\delta^{15} \mathrm{~N}\right)$ for a limited size
range of the native piranha Serrasalmus marginatus.
Manuscript received on July 31, 2019;

accepted for publication on May 18, 2020

\section{GUSTAVO H. ZAIA ALVES ${ }^{1,2}$}

https://orcid.org/0000-0002-9233-2824

\section{BRUNO R.S. FIGUEIREDO 3}

https://orcid.org/ 0000-0002-8750-808X

\section{GISLAINE I. MANETTA ${ }^{4}$}

https://orcid.org/0000-0003-3232-0984

\section{EVANILDE BENEDITO ${ }^{1,4}$}

https://orcid.org/0000-0002-3494-9949

${ }^{1}$ Programa de Pós-Graduação em Ecologia de Ambientes Aquáticos Continentais, Universidade Estadual de Maringá (UEM), Av. Colombo, 5790, Bloco G-90, 87020-900 Maringá, PR, Brazil

${ }^{2}$ Universidade Estadual de Ponta Grossa (UEPG), Setor de Ciências Biológicas e da Saúde, Departamento de Biologia Geral, Campus Uvaranas, Av. General C. Cavalcanti, 4748, 84030-900 Ponta Grossa, PR, Brazil ${ }^{3}$ Universidade Federal de Santa Catarina (UFSC), Centro de Ciências Biológicas, Departamento de Ecologia e Zoologia, Campus Universitário, Edifício Fritz Müller, Bloco B, 88040-970 Florianópolis, SC, Brazil

${ }^{4}$ Programa de Pós-Graduação em Biologia Comparada, Universidade Estadual de Maringá (UEM), Av. Colombo, 5790, Bloco G-80, 87020-900 Maringá, PR, Brazil

Correspondence to: Gustavo H. Zaia Alves

E-mail:alvesghz@yahoo.com.br

\section{Author contributions}

GHZA and EB conceived de study; GHZA, GIM and BRSF performed field sampling and laboratory analysis; GHZA performed data analysis and wrote the first draft of the manuscript. All authors contributed equally with valuable inputs, improving the manuscript.

\section{(cc) BY}

\section{How to cite}

ALVES GHZ, FIGUEIREDO BRS, MANETTA GI \& BENEDITO E. 2021. Ontogenetic diet shifts: an additional mechanism for successful invasion of a piranha species in a Neotropical floodplain. An Acad Bras Cienc 93: e20190868. DOI 10.1590/0001-3765202120190868. 